\title{
Presence of potential pathogenic genotypes of free-living amoebae isolated from sandboxes in children's playgrounds
}

\author{
Marcin Cholewiński, Piotr Solarczyk, Monika Derda, Agnieszka Wojtkowiak-Giera and Edward Hadaś
}

Department of Biology and Medical Parasitology, Faculty of Medicine I, Poznań University of Medical Sciences, Poznań, Poland

\begin{abstract}
Some free-living amoebae are a potential threat to human health. The best known species are those of the genus Acanthamoeba Volkonsky, 1931, which cause Acanthamoeba keratitis, granulomatous amoebic encephalitis and other forms of tissue inflammation. The aim of the present study was to search for potential pathogenic genotypes of free-living amoeba in the sand in children's playgrounds. Our results confirmed that free-living amoebae were present in all examined playgrounds. Sequences of the 18S rDNA have shown that all isolated potentially pathogenic strains of amoebae belong to genotype T4 of Acanthamoeba. The potential pathogenicity of isolates was confirmed on mice. The presence of pathogenic amoebae in the examined sand may be a potential source of human infection.
\end{abstract}

Keywords: genotyping, Acanthamoeba, parasites, molecular study

Free-living amoebae of the genera Acanthamoeba Volkonsky, 1931, Balamuthia Visvesvara, 1986, Echinamoeba Page, 1975, Hartmannella Page, 1975, Mastigina Frenzel, 1897, Naegleria Alexeieff, 1912, Saccamoeba Bovee, 1972, Vannella Bovee, 1965, Vexillifera Schaeffer, 1926 and others are organisms commonly occurring in the natural environment (Michel and Schneider 1980, Bolivar et al. 2001, Łanocha et al. 2009, Corsaro et al. 2010). Some feed on bacteria, fungi and other solid particles, and are well adapted to the natural environment (Gupta and Das 1999, Schuster et al. 2003). Trophozoites and cysts of amoebae are found in oceanic deposits, waste water, in bottled mineral water, swimming pools, air conditioners, on vegetables and mushrooms, as well as on nasal cavity swabs, pharyngeal swabs and in purulent secretions from the ear.

Several genera of amoebae are also known as amphizoic organisms, which means that as free-living organisms they are able to penetrate and multiply in host organisms - including the human body - and function as parasites (Geisen et al. 2015). Free-living amoebae are the subject of research conducted not only by biologists, but also by geneticists, microbiologists, cytologists and pathologists (Walochnik 2014). The human and animal pathogenicity of amoebae was first reported in 1958. Research performed by Culbertson et al. (1959) and Fowler and Carter (1965) described the first fatal instances of human encephalitis caused by species of Acanthamoeba. A few thousand cases of diseases caused by free-living amoebae have been described in the literature (Trabelsi et al. 2012).
Potentially, the most virulent and dangerous to humans are species and strains of the genera Acanthamoeba and Naegleria, as well as species and strains of the genera Balamuthia (see Siddiqui and Khan 2012, Walochnik 2014).

Amoebae of the genus Acanthamoeba may represent a potential etiological agent in granulomatous amoebic encephalitis (GAE), Acanthamoeba keratitis (AK), pneumonia (AP) and amoebic inflammation of the skin, as well as in other diseases of organs and tissue in both humans and animals. Amoebae of the genus Naegleria cause primary amoebic meningoencephalitis (PAME), usually fatal, whereas amoebae of the genus Balamuthia bring about symptoms and pathological changes similar to those occurring during an infection with Acanthamoeba spp. (Sriram et al. 2008, LaFleur et al. 2013, Mirjalali et al. 2013, van der Beek et al. 2015).

The objective of the present study was to search for potential pathogenic genotypes of free-living amoebae in the city's sandboxes on children's playgrounds. These amoebae can be a potential threat to human health, especially for children (Lorenzo-Morales et al. 2005) because inhalation of sand or invasion of eyes by sand or dust on playgrounds constitutes a potential risk of amoeba infection (Shamsuzzaman and Hashiguchi 2002, Conza et al. 2013, Todd et al. 2015).

\section{MATERIALS AND METHODS}

The samples of amoebae were isolated from wet sand in thirteen sandboxes on children's playgrounds in Poznań, Poland (Table 1). All sandboxes are not covered and exchange of sand takes 
Table 1. Pathogenicity of isolates of Acanthamoeba spp. from sandboxes on children's playgrounds in Poznań, Poland.

\begin{tabular}{lcccc}
\hline & & & & \multicolumn{2}{c}{ Invaded tissue } \\
\cline { 3 - 4 } Place of samples collection & Isolate name & Pathogenicity* & brain & lungs \\
\hline Zbigniew Zakrzewski Green Garden Square & AcP1 & $3 / 1 / 1$ & - & + \\
Zbigniew Zakrzewski Green Garden Square & AcP15 & $3 / 1 / 1$ & + & - \\
Solacki Park & AcP2 & $4 / 1 / 0$ & + & - \\
Izabela i Jarogniew Drweski Park & AcP7 & $4 / 3 / 0$ & + & - \\
Izabela i Jarogniew Drweski Park & AcP8 & $3 / 2 / 0$ & + & - \\
Izabela i Jarogniew Drweski Park & AcP17 & $4 / 3 / 0$ & + & + \\
Izabela i Jarogniew Drweski Park & AcP14 & $3 / 1 / 0$ & - & - \\
Rusalka Lake Park & AcP12 & $3 / 1 / 0$ & - & - \\
Henryk Wieniawski Park & AcP16 & $3 / 2 / 0$ & + & - \\
John Paul II Park & AcP13 & $3 / 1 / 0$ & + & + \\
John Paul II Park & AcP20 & $4 / 1 / 0$ & - & - \\
John Paul II Park & AcP21 & $3 / 1 / 1$ & - & - \\
John Paul II Park & AcP23 & $3 / 1 / 1$ & + & + \\
Adam Asnyk Square & AcP49 & $4 / 2 / 0$ & - & - \\
Adam Wodziczko Park & AcP54 & $4 / 1 / 0$ & + & - \\
Thomas Wilson Park & AcN4 & $4 / 0 / 0$ & - & - \\
Jurij Gagarin Park & AcN5 & $4 / 0 / 0$ & - & - \\
Grunwaldzka Street & AcN6 & $4 / 0 / 0$ & - & - \\
Malta Lake Park & AcN9 & $4 / 0 / 0$ & - & - \\
Gustaw Manitius Park & AcN10 & $4 / 0 / 0$ & - \\
\hline
\end{tabular}

* pathogenicity of the strains is expressed as the ratio of the number of animals inoculated to the number of infected and dead animals.

place two times in a year. For the study approximately $50 \mathrm{~g}$ of sand were collected in sterile disposable containers.

The amoebae were isolated by placement of about $1 \mathrm{~g}$ samples of sand on agar plates (diameter of $80 \mathrm{~mm}$ ). They were cultured at temperature of $28^{\circ} \mathrm{C}$ on $2 \%$ non-nutrient agar (Difco Laboratories, Detroit, USA) covered by bacteria (Enterobacter aerogenes strain 535i). After 3-5 days, an increase in the number of amoebae was observed and examined with a microscope at $200 \times$. The plates were monitored microscopically for up to two weeks for growth of trophozoites or for the presence of cysts. For monitoring, a Nicon (Precoptic Co., Warsaw, Poland) microscope was used.

The amoebae 2-3 days old obtained from NN agar culture were washed down with sterile distilled water. The suspension thus obtained was used to infect two-week-old mice, strain BALB/c, by intranasal inoculation (Mazur 1984). Autopsy was performed immediately after death of mice and pieces of the brain and the lungs were placed on NNE medium for culturing of amoebae. Mice that survived for over four weeks were anesthetised and their organs were examined. The brains and lungs of the mice, irrespective of the cause of death, were collected in order to isolate the amoebae. The amoebae isolated from tissues were identified according to morphological criteria, measurements of the size of cysts, and tests for flagellation (Page 1988, Smirnov et al. 2011).

DNA amplification was performed using genus-specific primers previously described by Schroeder et al. (2001). A set of primers that included the forward JDPI (5'GGCCCAGATCGTTTACCGTGAA'3), and the reverse primer JDP2 were used (5'TCTCACAAGCTGCTAGGGAGTCA'3) for genetic characterisation targeting an $\sim 450 \mathrm{bp}$ fragment of the Acanthamoeba $18 \mathrm{~S}$ ribosomal rRNA (rRNA) gene. Amplification involved use of a $25 \mu \mathrm{l}$ suspension of the following reagents: $2.5 \mathrm{mM} \mathrm{MgCl}$, $0.6-1 \mu \mathrm{M}$ of each primer, $0.2 \mathrm{mM}$ of each deoxynucleotide triphosphate, and 0.5 U of AmpliTaq Gold DNA polymerase. A clinical isolate of Acanthamoeba castellanii Douglas, 1930 belonging to the T4 genotype isolated from a keratitis patient (ATCC 50374) was used as a positive control. A negative control consisting of a reaction mixture without a DNA template was included.

Polymerase chain reaction (PCR) was carried out using a $\mathrm{Ge}-$ neAmp 2400 thermocycler. PCR products were analysed on $1 \%$ agarose gel stained with ethidium bromide. Gel images were illuminated using UV light and captured using a gel documentation system. PCR products were cleaned and sequenced in both directions with the same set of primers. Sequencing was performed with BigDye Terminator v3.1 on an ABI Prism 3130XL Analyzer (Applied Biosystems, Waltham, Massachusetts, USA). Trace files were checked and edited using FinchTV 1.3.1 (Geospiza Inc., Seattle, USA). Contigs were aligned and manually assembled in GeneDoc v. 2.7.000 (Nicholas and Nicholas Jr. 1997, Nicholas et al. 1997). Sequences were analysed using the program Chromas. Next, the gene sequence fragments of the isolates of Acanthamoeva were compared with the reference sequences deposited in GenBank (National Center for Biotechnology Information).

\section{RESULTS}

Free-living amoebae were found in all sandboxes, with pathogenic isolates detected in eight sandboxes (Table 1). Based on morphological characteristics of trophozoites or cysts and PCR, all isolates of pathogenic amoebae belonged to the genus Acanthamoeba. Pathogenic strains were obtained from the brain and the lungs of experimentally infected mice (Table 1).

DNA was isolated from 15 pathogenic samples and partial 18S rDNA sequences were obtained (see Table 2 for sequence accession numbers). Amplicons of the desired fragment were obtained from the amoeba isolates from two tissues of experimentally infected mice. Six strains of Acanthamoeba sp. were from the lungs: AcP1, AcP12, AcP14, AcP20, AcP21 and AcP49. Nine isolates of Acan- 
Table 2. Comparison of isolates of Acanthamoeba spp. from children's playgrounds in relation to reference strains deposited in GenBank (all isolates belonged to genotype T4).

\begin{tabular}{|c|c|c|c|c|c|c|}
\hline \multicolumn{3}{|c|}{ Isolates } & \multicolumn{4}{|c|}{ Nucleotide sequence similarity in relation to reference strains } \\
\hline $\begin{array}{l}\text { Isolate } \\
\text { name }\end{array}$ & $\begin{array}{l}\text { Re-isolatec } \\
\text { from tissue }\end{array}$ & $\begin{array}{l}\text { Accession } \\
\text { no. }\end{array}$ & Origin & & $\begin{array}{l}\text { Accession } \\
\text { no. }\end{array}$ & Reference \\
\hline AcP1 & $\mathrm{L}$ & KR259807 & $100 \%$ identity to Acanthamoeba sp., NI134 ex-arable fields, & Netherlands & KF928942 & Geisen et al. 2014 \\
\hline \multirow{3}{*}{$\mathrm{AcP} 2$} & \multirow{3}{*}{ B } & \multirow{3}{*}{ KR259808 } & $\begin{array}{l}100 \% \text { identity to Acanthamoeba } \text { sp., AcaVN10 swimming } \\
\text { pool scrape, }\end{array}$ & Slovakia & GQ397472 & Nagyová et al. 2010a \\
\hline & & & $\begin{array}{l}100 \% \text { identity to Acanthamoeba sp., Mbc_3E, a rice field of } \\
\text { the Istituto Sperimentale della Risicoltura, }\end{array}$ & Italy & AB425952 & Murase and Frenzel 2008 \\
\hline & & & $\begin{array}{l}100 \% \text { similarity to } A \text {. castellanii Neff, } 1957,1 \mathrm{BU} \text { keratitis } \\
\text { patient, cornea }\end{array}$ & Austria & AF260721 & Walochnik et al. 2000 \\
\hline AcP7 & B & KR259809 & \multirow{4}{*}{$\begin{array}{l}100 \% \text { identity to Acanthamoeba sp., DRB1 from Danube } \\
\text { river bank soil, (strain most closely related to A. castellanii) }\end{array}$} & \multirow{4}{*}{ Austria } & \multirow{4}{*}{ KF924599 } & \multirow{4}{*}{ Lagkouvardos et al. 2014} \\
\hline AcP13 & B & KR259812 & & & & \\
\hline $\begin{array}{l}\text { AcP16 } \\
\text { AcP49 }\end{array}$ & $\begin{array}{l}\text { B } \\
\text { L }\end{array}$ & $\begin{array}{l}\text { KR259815 } \\
\text { KR259820 }\end{array}$ & & & & \\
\hline AcP54 & $\mathrm{B}$ & KR259821 & & & & \\
\hline AcP8 & $\mathrm{B}$ & KR259810 & 99\% similarity to Acanthamoeba sp., 116MAF corneal scrape & France & DQ087324 & Yera et al. 2007 \\
\hline AcP12 & $\mathrm{L}$ & KR259811 & $\begin{array}{l}\text { 99\% similarity to Acanthamoeba } \text { sp., CDC\#V390 from non- } \\
\text { AK }\end{array}$ & USA & AY703004 & Booton et al. 2005 \\
\hline AcP14 & $\mathrm{L}$ & KR259813 & $\begin{array}{l}99 \% \text { similarity to Acanthamoeba } \text { sp., JPH13 from patient } \\
\text { with ocular infection }\end{array}$ & Japan & AB741047 & Rahman et al. 2013 \\
\hline \multirow[b]{2}{*}{ AcP15 } & \multirow[b]{2}{*}{ B } & \multirow[b]{2}{*}{ KR259814 } & \multirow{2}{*}{$\begin{array}{l}\text { 99\% similarity to Acanthamoeba sp., AG-2012 swamp water } \\
\text { 99\% similarity to Acanthamoeba } \text { sp., AcaVNAK03 from } \\
\text { corneal scrape }\end{array}$} & Spain & JQ678625 & Garcia et al. 2013 \\
\hline & & & & Slovakia & GQ905497 & Nagyová et al. 2010b \\
\hline \multirow{2}{*}{ AcP17 } & \multirow{2}{*}{ B } & \multirow{2}{*}{ KR259816 } & $\begin{array}{l}100 \% \text { identity to Acanthamoeba sp., DRS3 from the River } \\
\text { Danube sediment, }\end{array}$ & Austria & KF924603 & Lagkouvardos et al. 2014 \\
\hline & & & $\begin{array}{l}100 \% \text { identity to Acanthamoeba sp., AcaVN11 from air } \\
\text { conditioner scrape }\end{array}$ & Slovakia & GQ397473 & Nagyová et al. 2010b \\
\hline AcP20 & $\mathrm{L}$ & KR259817 & $\begin{array}{l}100 \% \text { identity to Acanthamoeba sp., 116MAF from corneal } \\
\text { scrape }\end{array}$ & France & DQ087324 & Yera et al. 2007 \\
\hline \multirow{3}{*}{$\begin{array}{l}\text { AcP21 } \\
\text { AcP23 }\end{array}$} & \multirow{3}{*}{$\begin{array}{l}\mathrm{L} \\
\mathrm{B}\end{array}$} & \multirow{3}{*}{$\begin{array}{l}\text { KR259818 } \\
\text { KR259819 }\end{array}$} & $\begin{array}{l}100 \% \text { identity to Acanthamoeba sp. SM6 6A from a rice } \\
\text { field of the Istituto Sperimentale della Risicoltura, }\end{array}$ & Italy & AB425948 & Murase and Frenzel 2008 \\
\hline & & & $100 \%$ identity to $A$. hatchetti Sawyer, $1977,2 \mathrm{HH}$ & Austria & AF260722 & Walochnik et al. 2000 \\
\hline & & & $\begin{array}{l}100 \% \text { identity to Acanthamoeba } \text { sp., BP:P8:LCS/T4 from } \\
\text { corneal scrape }\end{array}$ & Italy & FJ422512 & Ledee et al. 2009 \\
\hline
\end{tabular}

L - lung; B - brain; AK - Acanthamoeba keratitis.

thamoeba sp. were from the brains: AcP2, AcP7, AcP8, AcP13, AcP15, AcP16, AcP17, AcP23 and AcP54. No double peaks in the chromatograms occurred in the tested locus.

The results showed (Table 2) that the obtained sequence from the isolate AcP1 shared $100 \%$ identity with the sequence from the isolate NI134 of Acanthamoeba sp. obtained from an ex-arable field (GenBank accession No. KF928942; see Geisen et al. 2014). It was found that the DNA sequences of the fragment of the gene 18S rRNA of AcP2 was $100 \%$ identical to the reference sequences of the Acanthamoeba strains AcaVN10 (GQ397472) from a swimming pool scrape (Nagyová et al. 2010a) and Mbc_3E (AB425952) from a rice field and 1BU (AF260721) from a cornea (Walochnik et al. 2000).

The comparison of the sequences at the same molecular marker of the isolates AcP7, AcP13, AcP16, AcP49 and AcP54 with the sequences deposited in GenBank also showed $100 \%$ identity to the sequence of this gene of the parasite isolated from the environmental sample DRB1 (KF924599) from bank soil of the River Danube in Austria (Lagkouvardos et al. 2014). The isolate AcP17 was identical in its nucleotide sequence to strain DRS3 (KF924603) from the River Danube (Lagkouvardos et al. 2014) and strain AcaVN11 (GQ397473) from an air conditioner scrape in Slovakia (Nagyová et al. 2010b).
The sequence of the isolate AcP20 was identical to the sequence from strain 116MAF (DQ087324) from a corneal scrape in France (Yera et al. 2007). The sequences from the isolates AcP21 and AcP23 were also identical to the sequences of the same molecular marker from strains SM6_6A (AB425948) from a rice field in Italy (Murase and Frenzel 2008), strain 2HH (AF260722) (Walochnik et al. 2000) and strain BP:P8LCS/T4 (FJ422512) from a corneal scrape in Italy (Ledee et al. 2009).

The 18S DNA sequence from the environmental isolate AcP8 displayed 99\% identity with the sequences of the same marker from corneal scraping 116MAF (DQ087324) and had one single-nucleotide polymorphisms (SNP) (Yera et al. 2007). Sequencing of the AcP12 and AcP14 isolate also showed that the molecular marker sequence was 99\% identical to the sequence of Acanthamoeba strains CDC\#V390 (AY703004) from USA (Booton et al. 2005) and JPH13 (AB741047) from patients in Japan (Rahman et al. 2013) and differed in three to four SNP to the compared marker. The genotyping results showed that the sequence from Acanthamoeba AcP15 shared 99\% identity to the sequence from the swamp water Acanthamoeba isolate AG2012 (JQ678625) (Garcia et al. 2013) and AcaVNAK03 (GQ905497) obtained from a corneal scrape (Nagyová et al. 2010b). Compared sequences differed by one SNP. 


\section{DISCUSSION}

The research conducted has shown that sand on children's playgrounds in sandboxes is not free of free-living amoebae, including potentially pathogenic strains thereof. It has been determined that amoebae are present in all of the analysed sandboxes in the city of Poznan. The results of the pathogenicity of amoebae have brought to light their potential invasive properties. Experimental infections of mice showed that amoebae were present in the tissues of animals. In the majority of cases, amoebae were isolated from the brain or lung tissue of animals. We may therefore assume that it is probable that granulomatous amoebic encephalitis, Acanthamoeba keratitis and pneumonia may be caused in immunocompromised individuals who have come into contact with sand or dust on the children's playgrounds.

Should the presence of amoebae in sandboxes on children's playgrounds be a cause for concern? Can free-living amoebae constitute a real hazard to the participants playing in sandboxes? No clear-cut answer is available. Routine inspections of sand and sandboxes do not serve to determine the presence of pathogenic amoebae. However, when such research was conducted worldwide, it revealed that amoebae are present in $100 \%$ of inspected samples. Moreover, free-living amoebae may be isolated not only from moist soil and sand, but also from dust (Booton et al. 2004, Lorenzo-Morales et al. 2005, Geisen et al. 2014).

The lack of screening of municipal children's playgrounds may contribute to an increase in human amoebic infections. Furthermore, cysts of Acanthamoeba spp. are not only resistant to the action of numerous physical and chemical agents (considerable temperature fluctuations, drying, radiation) (Sriram et al. 2008, Siddiqui and Khan 2012), but may also function as carriers of pathogenic bacteria (Winniecka-Krusnell and Linder 2001, Derda et al. 2006, Khan and Siddiqui 2014). A special role may be played in this regard by amoebae belonging to non-pathogenic species or genera, for example Naegleria gruberi Schardinger, 1899, Dictiostellium discoideum Raper, 1935, species of Hartmannella and Vannella (see Lasjerdi et al. 2011). The fact that amoebae are carriers of other microorganisms (Hadaś et al. 2004) represents an additional challenge. Results of the present study turns our attention to the necessity of broadening routine checks for potentially pathogenic amoebae in sandboxes on children's playgrounds.

\section{REFERENCES}

van der Beek N.A.M.E., van Tienen C., De HaAn J.E., RoelfSema J., Wismans P.J., van GenderenP.J.J., Tanghe H.L., Verdijk R.M., Titulaer M.J., van Hellemond J.J. 2015: Fatal Balamuthia mandrillaris meningoencephalitis in the Netherlands after travel to the Gambia. Emerg. Infect. Dis. 21: 896-898.

Bolivar I., Fahrni J.F., Smirnov A., Pawlowski J. 2001: SSU rRNA-based phylogenetic position of the genera Amoeba and Chaos (Lobosea, Gymnamoebia): the origin of gymnamoebae revisited. Mol. Biol. Evol. 18: 2306-2314.

Booton G.C., Rogerson A., Bonilla T.D., Seal D.V., Kelly D.J., Beattie T.K., Tomlinson A., Lares-Villa F., Fuerst P.A., Byers T.J. 2004: Molecular and physiological evaluation of subtropical environmental isolates of Acanthamoeba spp. causal agent of Acanthamoeba keratitis. J. Eukaryot. Microbiol. 51: 192-200.

Booton G.C., Visvesvara G.S., Byers T.J., Kelly D.J., Fuerst P.A. 2005: Identification and distribution of Acanthamoeba species genotypes associated with nonkeratitis infections. J. Clin. Microbiol. 43: 1689-1693.

Conza L., Pagani S.C., Gaia V. 2013: Presence of Legionella and free-living Amoebae in composts and bioaerosols from compositing facilities. PLoS ONE 8: e68244.

Corsaro D., Michel R., Walochnik J., Müller K.D., Greub G. 2010: Saccamoeba lacustris, sp. nov. (Amoebozoa: Lobosea: Hartmannellidae), a new lobose amoeba, parasitized by the novel chlamydia 'Candidatus Metachlamydia lacustris' (Chlamydiae: Parachlamydiaceae). Eur. J. Protistol. 46: 86-95.

Culbertson C.G., Smith J.W., Minner J.R. 1959: Experimental infection of mice and monkeys by Acanthamoeba. Am. J. Pathol. 35: $185-197$.

Derda M., SuŁek-Stankiewicz A., Hadaś E. 2006: Free-living amoebae as vehicles of pathogenic bacteria. Wiad. Parasitol. 52: $1-7$.

Fowler M., CARTER R.F. 1965: Acute pyogenic meningitis probably due to Acanthamoeba sp.: a preliminary report. British. Med. J. 2: 740-742.

Garcia A., Goni P., Cieloszyk J., Fernandez M.T., Calvo-Begueria L., Rubio E., Fillat M.F., Peleato M.L., Clavel A.
2013: Identification of free-living amoebae and amoeba-associated bacteria from reservoirs and water treatment plants by molecular techniques. Environ. Sci. Technol. 47: 3132-3140.

Geisen S., Fiore-Donno A.M., Walochnik J., Bonkowski M. 2014: Acanthamoeba everywhere: high diversity of Acanthamoeba in soils. Parasitol. Res. 113: 3151-3158.

Geisen, S., Laros, I., Vizcaíno, A., Bonkowski, M., De Groot, G.A. 2015: Not all are free-living: high-throughput DNA metabarcoding reveals a diverse community of protists parasitizing soil metazoa. Mol. Ecol. 24: 4556-4569.

Gupta S., DAs S.R. 1999: Stock cultures of free-living amebas: effect of temperature on viability and pathogegenicity. J. Parasitol. 85: 137-139.

Hadaś E., Derda M., Winiecka-Krusnell J., SuŁeK A. 2004: Acanthamoeba spp. as vehicles of pathogenic bacteria. Acta Parasitol. 49: 276-280.

Khan N.A., SiddiQui R. 2014: Predator vs aliens: bacteria interactions with Acanthamoeba. Parasitology 141: 869-874.

LaFleur M., Jyner D., Schlakman B., Orozco-Castillo L., KHAN M. 2013: Balamuthia mandrillaris meningoencephalitis associated with solid organ transplantation - review of cases. J. Radiol. Rep. 7: 9-18.

Lagkouvardos I., Shen J., Horn M. 2014: Improved axenization method reveals complexity of symbiotic associations between bacteria and acanthamoebae. Environ. Microbiol. Rep. 6: 383388 .

Łanocha N., Kosik-Bogacka D., Kuźna-Grygiel W. 2009: The role of free-living amoebae in pathogenesis and transmission of human and animals diseases. Probl. Hig. Epidemiol. 90: $165-170$.

Lasjerdi Z., Niyyati M., Haghighi A., Zaeri F., NazemalHosseini Mojarad E. 2011: First report of Vannellidae amoebae (Vannella spp.) isolated from biofilm source. Iran J. Parasitol. 6: 84-89.

Ledee D.R., Iovieno A., Miller D., Mandal N., Diaz M., Fell J., Fini M.E., Alfonso E.C. 2009: Molecular identification of $\mathrm{t} 4$ and $\mathrm{t} 5$ genotypes in isolates from Acanthamoeba keratitis patients. J. Clin. Microbiol. 47: 1458-1462. 
Lorenzo-Morales J., Monteverde-Miranda C.A., Jiménez C., Tejedor M.L., Valladares B., Ortega-Rivas A. 2005: Evaluation of Acanthamoeba isolates from environmental sources in Tenerife, Canary Islands, Spain. Ann. Agric. Environ. Med. 12: 233-236.

MAZuR T. 1984: [Occurrence of Naegleria fowleri in a free environment and biological properties of isolated strains.] Wiad. Parazytol. 30: 3-35. (In Polish.)

Michel R., Schneider H. 1980: Studies of limax-amoebae in a physiotherapeutical indoor-swimming-pool. Zentralbl. Bakteriol. B. 170: 479-491.

Mirjalali H., Niyyati M., Abedkhojasteh H., Babaei Z., Sharifdini M., Rezaeian M. 2013: Pathogenic assays of Acanthamoeba belonging to the T4 genotype. Iran J. Parasitol. 8: $530-535$.

Murase J., Frenzel P. 2008: Selective grazing of methanotrophs by protozoa in a rice field soil. FEMS Microbiol. Ecol. 65: 408414.

Nagyová V., Nagy A., JAneČek Š. Timko J. 2010b: Morphological, physiological, molecular and phylogenetic characterization of new environmental isolates of Acanthamoeba spp. from the region of Bratislava, Slovakia. Biologia 65: 81-91.

Nagyová V., Nagy A., Timko J. 2010a: Morphological, physiological and molecular biological characterisation of isolates from first cases of Acanthamoeba keratitis in Slovakia. Parasitol. Res. 106: 861-872.

Nicholas K.B., Nicholas H.B. JR. 1997: GeneDoc: a tool for editing and annotating multiple sequence alignments. Distributed by the authors. www.cris.com/ketchup/genedoc.shtml.

Nicholas K.B., Nicholas H.B. JR., Deerfield D.W.I. 1997: GeneDoc: analysis and visualization of genetic variation. EMBNETnews 4: 1-22.

Page F.C. (ED.) 1988: A new key to freshwater and soil Gymnamoebae with instruction for culture. Freashwater Biological Association, Ambleside, Cumbria, 5-15 pp.

Rahman M.M., Yagita K., Kobayashi A., Oikawa Y., Hussein A.I., Matsumura T., Tokoro M. 2013: Genetic characterization of clinical Acanthamoeba isolates from Japan using nuclear and mitochondrial small subunit ribosomal RNA. Kor. J. Parasitol. 51: 401-411.

Schroeder J.M., Booton G.C., Hay J., Niszl I.A., Seal D.V., Markus M.B., Fuerst P.A., Byers T.J. 2001: Use of subgenic $18 \mathrm{~S}$ ribosomal DNA PCR and sequencing for genus and geno- type identification of acanthamoebae from humans with keratitis and from sewage sludge. J. Clin. Microbiol. 39: 1903-1911.

Schuster F.L., Dunnebacke T.H., Booton G.C., Yagi S., Kohlmeier C.K., Glaser C., Vugia D., Bakardjiev A., Azimi P., Maddux-Gonzalez M., Martinez A.J., VisvesVARA G.S. 2003: Environmental isolation of Balamuthia mandrillaris associated with a case of amebic encephalitis. J. Clin. Microbiol. 41: 3175-3180.

Shamsuzzaman S.M., Hashiguchi Y. 2002: Thoracic amebiasis. Clin. Chest. Med. 32: 479-492.

Siddiqui R., Khan N.A. 2012: Biology and pathogenesis of Acanthamoeba. Parasit. Vectors 5: 6.

Smirnov A.V., Chao E., Nassonova E.S., Cavalier-Smith T. 2011: A revised classification of naked lobose amoebae (Amoebozoa: Lobosa). Protist 162: 545-570.

Sriram R., Shoff M., Booton G., Fuerst P., Visvesvara G.S. 2008: Survival of Acanthamoeba cyst after desiccation for more than 20 years. J. Clin. Microbiol. 46: 4045-4048.

Todd C.D., Reyes-Batlle M., Martin-Navarro C.M., Dorta-Gorrin A., Lopez- Aencibia A., Martinez-Carretero E., Pinero J.E., Valladares B., Lindo J.F., Lorenzo-MoRALES J. 2015: Isolation and genotyping of Acanthamoeba strains from soil source from Jamaica, West Indies. J. Eukaryot. Microbiol. 62: 416-421.

Trabelsi H., Dendana F., Sellami A., Sellami H., Cheikhrouhou F., Neji S., Makni F., Ayadi A. 2012: Pathogenic free-living amoebae: epidemiology and clinical review. Pathol. Biol. (Paris) 60: 399-405.

WALOCHNiK J. 2014: Free-living amoebae: ecology, phylogeny, pathogenicity, susceptibility and interactions with other cells. Exp. Parasitol. 145: S1.

Walochnik J., Obwaller A., Aspock H. 2000: Correlations between morphological, molecular biological, and physiological characteristics in clinical and nonclinical isolates of Acanthamoeba spp. Appl. Environ. Microbiol. 66: 4408-4413.

WinieCKA-KruSNELl J., LiNDER E. 2001: Bacterial infections of free-living amoebae. Res. Microbiol. 152: 613-619.

Year H., Zamfir O., Bourcier T., Ancelle T., Batellier L., Dupouy-Camet J., Chaumeil C. 2007: Comparison of PCR, microscopic examination and culture for the early diagnosis and characterization of Acanthamoeba isolates from ocular infections. Eur. J. Clin. Microbiol. Infect. Dis. 26: 221-224. 